\title{
$\mathrm{DB}$ 구축을 통한 강원지역 토석류 유형 분석
}

전경재* $\cdot$ 김기홍** . 윤찬영***

Jun, Kyoung-Jea*, Kim, Gi-hong**, Yune, Chan-Young***

\section{Analysis of Debris Flow Type in Gangwon Province by Database Construction}

\begin{abstract}
In recent years in Korea, Typhoon Rusa (2002), Typhoon Maemi (2003), and the localized extreme rainfall followed by Typhoon Ewiniar in 2006 devastated residential areas, roads, and agricultural lands in Gangwon province where $90 \%$ of the area is in mountainous regions. Most of the economic losses and casualties were concentrated in the area near the mountain valleys and creeks due to the floods and debris flows. In this study, DATABASE, which includes a total 180 debris flow events in the Gangwon area, was created by collecting the hazard records and field investigations of existing debris flow sites. Analysis results showed that the most of the debris flows in Gangwon province initiated from the small slope failure with relatively steep slope of $34.3^{\circ}$. And they flowed short distances about $420 \mathrm{~m}$ in gentle slope with the average angle of $18.1^{\circ}$. In addition, rainfall condition was important for the triggering of debris flow not only at the day of debris flow but also extended period of rainfall before debris flow.
\end{abstract}

Key words : debris flow, DATABASE, field investigation, rainfall threshold

초 록 : 최근 우리나라에서는 2002년 태풍 루사, 2003년 태풍 매미, 2006년 태풍 에위니아와 집중호우로 인하여 산지가 약 $90 \%$ 를 차지 하고 있는 강원지역의 주택, 도로, 농지가 큰 피해를 입었다. 이로 인한 경제적 손실과 사망자의 대부분은 홍수와 토석류가 발생된 산지 계곡부와 시내에 집중되었다. 본 연구에서는 기존에 강원지역에서 발생된 토석류 발생지에 대한 현장조사를 실시하여 총 180 개소의 토 석류에 대한 데이터베이스를 구축하였다. 구축된 자료에 대한 분석결과, 강원지역에서 발생된 토석류는 대부분 소규모 사면파괴로부터 시작하였으며, $34.3^{\circ}$ 의 비교적 가파른 경사에서 발생하여 평균 $18.1^{\circ}$ 정도의 완만한 경사를 따라 $420 \mathrm{~m}$ 정도의 비교적 짧은 거리를 이 동하는 것으로 나타났다. 또한, 토석류 발생 당일의 강우도 중요하지만 발생 이전의 장기강우가 토석류 발생과 밀접한 관련이 있는 것으 로 나타났다.

검색어 : 토석류, 데이터베이스, 현장조사, 임계강우

\section{1. 서 론}

우리나라는 전 국토의 70\%이상이 산지로 이루어져 있으며, 매년 여름철 6월 9월 사이에 태풍 및 집중호우로 인해 발생된

\footnotetext{
* 강릉원주대학교 토목공학과 박사과정 (lgnampyon@nate.com)

** 정회원·강릉원주대학교 토목공학과 부교수 (ghkim@gwnu.ac.kr)
}

*** 정회원·강릉원주대학교 토목공학과 부교수 (Comresponding Author·Gangneung-Wonju National University, Associate Professor·yune@gwnu.ac.kr)

Received July 12 2012, Revised August 9 2012, Accepted December 262012 
$\mathrm{DB}$ 구축을 통한 강원지역 토석류 유형 분석

Table 1. Statistical data of recent damages by heavy rainfall and typhoon

\begin{tabular}{l|c|c|c|c|c|c}
\hline \hline \multirow{2}{*}{ Classification } & \multicolumn{2}{|c|}{ Total in Korea } & \multicolumn{2}{c|}{ Gangwon Province } & \multicolumn{2}{c}{ Percentage of Gangwon Province (\%) } \\
\cline { 2 - 8 } & Casualties & $\begin{array}{c}\text { Property Loss } \\
\text { (Billion Won) }\end{array}$ & Casualties & $\begin{array}{c}\text { Property Loss } \\
\text { (Billion Won) }\end{array}$ & Casualties & Property Loss \\
\hline Typhoon Rusa (2002) & 321 & $5,147.9$ & 178 & $2,530.5$ & 55.5 & 49.2 \\
\hline Typhoon Maemi (2003) & 132 & $4,775.7$ & 13 & 827.9 & 10.3 & 17.3 \\
\hline Regional Rainfall (2006) & 61 & $2,148.5$ & 42 & $1,577.7$ & 68.9 & 73.4 \\
\hline
\end{tabular}

사면붕괴 및 토석류와 같은 사면재해로 많은 인명 및 재산피해가 발생하고 있다. Table 1의 최근 재해현황을 살펴보면 2002년 태풍 '루사'의 경우 총 321 명의 인명피해와 5 조 1,479 억원의 재산피해가 발생한 것으로 집계되었으며(NDMI, 2002), 2003 년 태풍 ‘매미'의 경우 총 132 명의 인명피해와 4조 7,757억원의 재산피해가 발생한 것으로 집계되었다(NDMI, 2003). 또한, 2006년 태풍 '에위니아'에 이은 집중호우로 인해 총 61 명의 인명피해와 2 조 1,485 억원의 재산피해가 발생한 것으로 집계되 었다(Ministry of Construction and Transportation, 2006). 이러한 피해는 특히 산지가 $90 \%$ 이상을 차지하는 강원지역에서 많이 발생하고 있는데, 강원지역의 면적이 대한민국 전체 면적 대비 $17 \%$ 임을 감안하면 많은 재해가 강원도에 집중되고 있다는 사실을 알 수 있다. 특히 산지가 많은 강원지역의 특성 상 이러한 재해의 상당부분이 사면붕괴 및 토석류로 나타나고 있으며, 사면재해 중에서도 인명 및 재산피해를 유발하는 대부 분의 재해는 토석류 재해이다.

이와 같은 토석류 재해 및 그로 인한 피해를 저감하기 위해서 는 현장조사를 통하여 발생현황을 조사하고 국내 토석류의 발생 특성과 유형을 분석하는 것이 매우 중요하다. 국내에서는 Yune et al.(2010), Yoo et al.(2008)이 산사태 발생현장에 대한 현장조사 및 자료수집을 수행하여 분석한 사례들이 있으나 토석류만을 분석한 것이 아니고 다른 사면재해까지 포괄적으로 분석한 것이며, 기존 다른 국내 연구에서도 산사태를 연구하면 서 간접적으로 다루거나 해석적 연구만 일부 이루어졌을 뿐 토석류 발생현장에 대한 광범위한 조사, 분석을 통하여 국내 토석류의 특징을 파악하고 그 유형을 분석한 연구는 찾아보기 어렵다.

이 연구에서는 우리나라에서 가장 많은 토석류 재해가 발생하 고 있는 강원도 지역에 대하여 지속적인 현장조사와 기상청의 강우량 자료수집, 지형 및 지질자료 수집 등을 통하여 재해 데이터베이스를 구축하고 토석류 유형 분석의 기초자료로 활용 하였다. 구축된 데이터베이스는 발생부, 유하부, 유역, 강우량 등의 측면에서 분석하였으며, 이를 통하여 강원지역의 토석류 유형 특성을 확인하였다.

\section{2. 데이터베이스의 구축}

강원지역 토석류 유형 분석을 위하여 2002년 이후 강원지역 에서 발생한 토석류에 대한 현장조사를 수행하였다. 토석류가 발생한 지역은 강원 산간지역에 광범위하게 분포하고 있지만, 발생한 토석류가 도로와 같은 기간시설 등에 실제로 피해를 유발한 현장에 대하여 집중적인 조사를 수행하였다. 강원도 전역의 고속도로, 국도 및 지방도 인접 지역에서 발생한 토석류 현장에 대하여 개략조사를 수행하였으며, 개략조사 지역 중에서 상세조사가 필요한 지역에 대한 우선순위를 정하여 토석류 발생부와 유하부에 대한 상세조사를 수행하였다. 조사가 수행된 지역은 주로 인제와 평창 지역에 집중되어 있었는데, 인제는 고생대 이전에 형성된 편마암류와 중생대에 이를 관입한 화강암 류가 지표에 노출된 지역이 많으며, 평창은 선캄브리아기와 중생대의 편마암과 퇴적암이 주로 분포하고 있다.

3 년간 총 180 개소에 대하여 상세조사를 실시하였으며, 토석 류 발생부와 유하부를 포함하는 유역에 대하여 수치지형도 (DEM, Digital Elevation Map)를 이용한 분석작업을 실시하 였다. 이 때 하나의 유역에 대하여 출구부는 하나이지만 유역내 에서 다수의 발생부와 이동경로를 가지는 경우가 많으므로 180 개의 토석류 조사 자료를 유역별로 정리하면 총 85 개의 유역으로 나눌 수 있었다.

발생부에 대해서는 파괴형태, 사면경사, 발생부 부피를 조사 하였고, 유하부에 대해서는 20 30 m마다 길이, 경사, 이동방 향 등을 측정하였다. 또한 수치지형도를 이용하여 토석류 발생 부를 포함하는 유역에 대한 유역의 면적, 평균경사, 경사향을 산정하였다.

강우자료는 기상청의 자동가상관측시스템(AWS, Automation Weather System)에서 재해발생 당시의 시간단위 강우량 자료 를 수집하였다. 단, 토석류 현장은 과거에 토석류가 발생한 현장에 대하여 조사를 수행하게 되므로, 발생일까지는 확인가능 하지만 정확한 발생시간은 확인하지 못한 경우가 많았다. 따라 서 데이터베이스 구축에 사용된 강우자료는 발생일을 기준으로 최대시간강우량, 연속강우량, 3 일누적강우량, 28 일누적강우량 
Table 2. Structure of DATABASE

\begin{tabular}{l|l|l}
\hline \hline Classification & Field & Obtained by \\
\hline Initiation zone & $\begin{array}{l}\text { Volume } \\
\text { (Width, Length, Depth) } \\
\text { Slope angle } \\
\text { Failure type }\end{array}$ & \multirow{2}{*}{ Field survey } \\
\cline { 1 - 2 } $\begin{array}{l}\text { Transportation } \\
\text { zone }\end{array}$ & $\begin{array}{l}\text { Average gradient } \\
\text { Transportation distance }\end{array}$ & \\
\hline Basin & $\begin{array}{l}\text { Basin area } \\
\text { Average gradient }\end{array}$ & \multirow{2}{*}{ Digital elevation map } \\
\hline Rainfall & $\begin{array}{l}\text { Max. hourly rainfall } \\
\text { Continuous rainfall } \\
3 \text { days cumulative rainfall }\end{array}$ & $\begin{array}{l}\text { AWS } \\
\text { (Automatic Weather } \\
\text { Station) }\end{array}$ \\
& $\begin{array}{l}28 \text { days cumulative rainfall } \\
\end{array}$ & \\
\hline
\end{tabular}

으로 정리하였다.

이러한 현장조사결과와 강우량조사 결과를 바탕으로 토석류 재해 데이터베이스를 구축하였으며, 데이터베이스는 지금도 지속적으로 조사를 진행하면서 자료를 업데이트하고 있다. 이상 과 같이 구축된 데이터베이스의 구조를 정리하면 다음 Table 2 와 같으며, 앞으로 지속적인 현장조사를 통하여 데이터베이스가 가 확충되면 향후 한국 토석류에 대한 재해위험지 선정, 조기경 보시스템 구축 등에도 활용할 수 있을 것으로 기대된다.

\section{3. 토석류 발생부 특성}

\section{1 발생부의 부피}

현장조사를 수행한 총 180 개소의 토석류 중에서 사면붕괴로 부터 시작된 토석류는 177 개소로 나타났다. 반면에 3 개소는 발생부를 명확히 확인할 수 없어 강우로 인하여 계곡부에서 유량이 증가하고 그에 따라 세굴 및 구곡침식에 의하여 토석류가 시작된 것으로 판단된다. Fig. 1에 나타낸 것은 사면붕괴로부터 시작된 토석류 유형에 대한 발생부의 부피이다. 여기서 최소, 최대, 평균 부피는 각각 $16,18,450,1,293 \mathrm{~m}^{3}$ 로 나타났으며, 총 177 개소 중 $1,000 \mathrm{~m}^{3}$ 미만인 것이 129 개소 $(72.9 \%)$ 로 가장 높은 빈도를 보였다. 가장 높은 빈도를 보인 $1,000 \mathrm{~m}^{3}$ 미만의 발생부에 대하여 $100 \mathrm{~m}^{3}$ 단위로 Fig. 1 (b)와 같이 다시 도시한 결과, $100 \mathrm{~m}^{3} \sim 200 \mathrm{~m}^{3}$ 에서 가장 높은 빈도를 보였으며, 1,000 $\mathrm{m}^{3}$ 미만 발생부의 평균부피는 $335 \mathrm{~m}^{3}$ 으로 나타났다. 이는 강원지역에서 발생하는 토석류가 대부분 $1,000 \mathrm{~m}^{3}$ 미만의 소규 모 사면붕괴로부터 시작된다는 것을 의미한다.

\section{2 발생부의 경사}

총 180 개소의 발생부에 대하여 사면경사를 분석하였다. 그

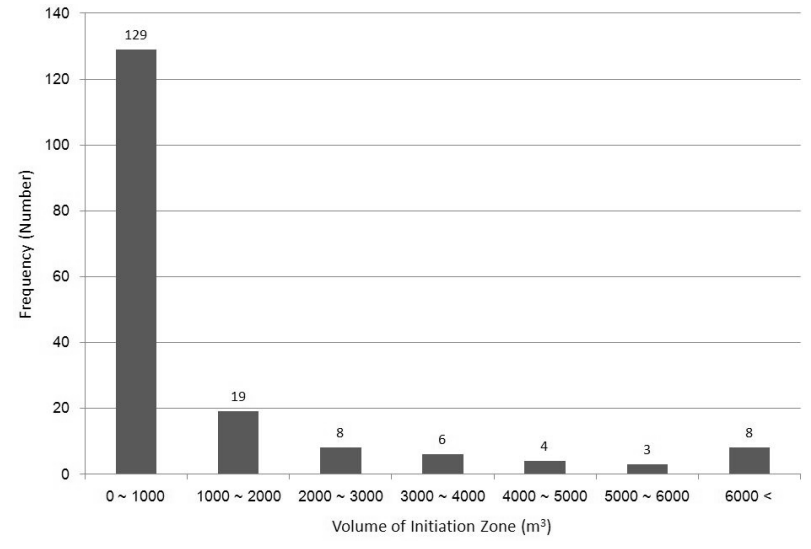

(a) Volume of initiation zone(177 sites)

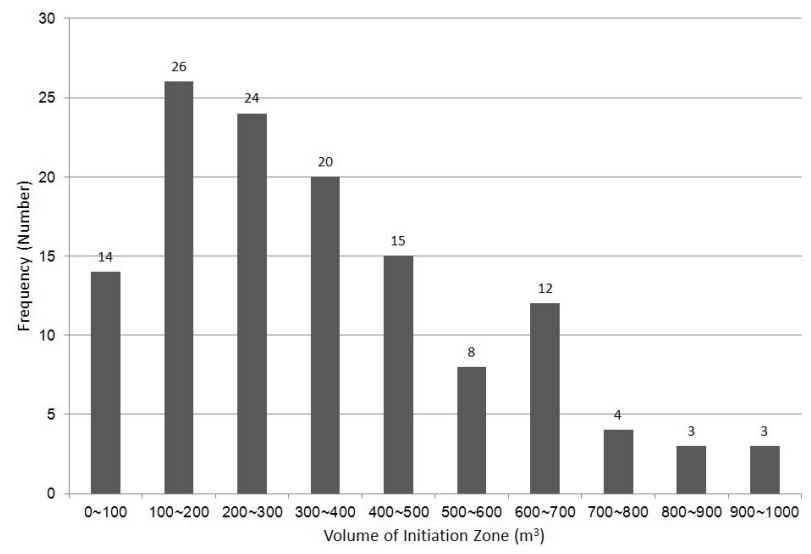

(b) Volume of initiation zone below $1,000 \mathrm{~m}^{3}$ (129 sites)

Fig. 1. Volume of initiation zone in Gangwon province(177 sites)

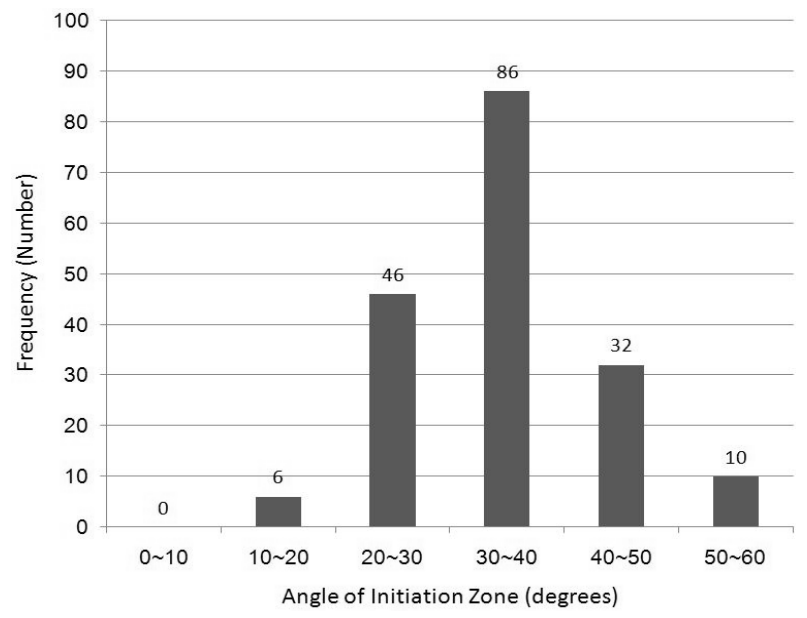

Fig. 2. Angle of initiation zone in Gangwon province(180 sites)

결과 발생부의 경사는 $10^{\circ} \sim 58^{\circ}$ 의 범위를 갖는 것으로 나타났 으며, 그 중 가장 빈도가 높은 경사는 $38^{\circ}$, 평균값은 $34.3^{\circ}$ 로 나타났다. Fig. 2 와 같이 $10^{\circ}$ 간격으로 나타낸 결과, $30^{\circ} \sim 40^{\circ}$ 의 
범위에서 가장 높은 빈도(47.8\%, 86개소)를 보였다. 이전의 연구에서 토석류 발생부의 경사 중 가장 높은 빈도가 한국의 경우에는 $26^{\circ} \sim 30^{\circ}$ 로(Kim et al., 2006), 일본의 경우에는 $10^{\circ} \sim 20^{\circ}$ 로(keya, 1989) 나타난 사실을 고려해 볼 때, 강원지 역의 토석류는 상대적으로 급한 경사에서 발생하였다는 사실을 알 수 있다.

\section{3 발생부의 파괴형태}

토석류 발생부에 대한 현장조사를 통하여 발생부의 파괴형태 를 조사하였다. 이러한 조사를 통하여 평면파괴, 원호파괴, 쐐기 파괴, 복합파괴, 구곡침식 총 5 가지의 파괴형태가 조사되었다. 조사된 자료를 분석해본 결과, 평면파괴가 $74.4 \%$ 로 가장 높은 빈도를 보였으며, 그 다음으로는 원호파괴( $20.6 \%)$, 복합파괴 (2.2\%), 구곡침식(1.7\%), 쐐기파괴(1.1\%)의 순서로 나타났다.

\section{4 발생부의 형상과 심도}

총 180 개소의 발생부 중에서 현장조사 이전에 복구가 완료되

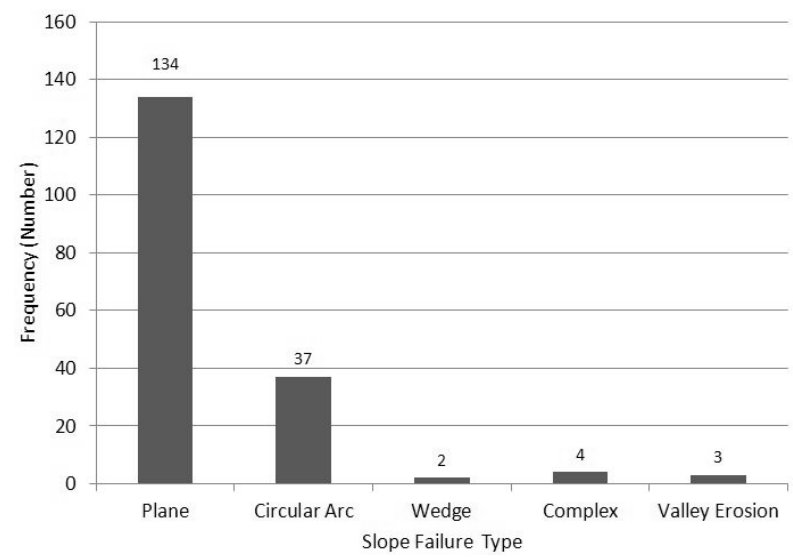

Fig. 3. Slope failure type of initiation zone in Gangwon province (180 sites)

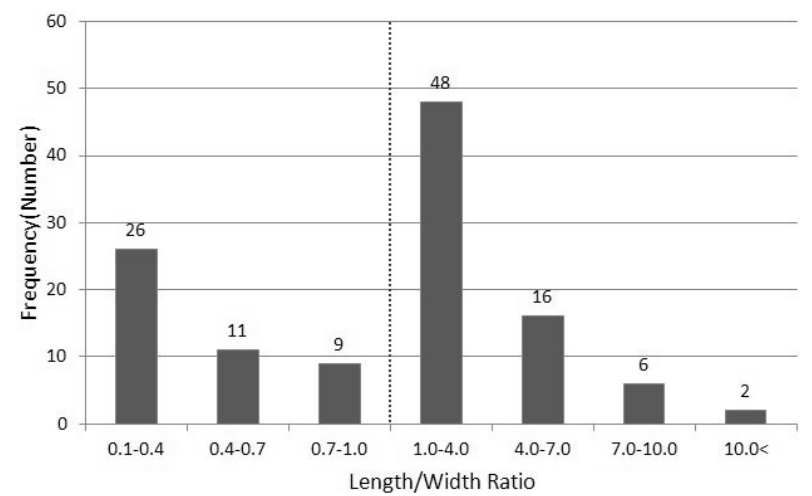

Fig. 4. Length/width ratio of initiation zone in Gangwon province (118 sites)
어 발생부의 경계가 명확하지 않은 지역을 제외한 총 118 개소에 대하여 발생부의 길이, 폭과 심도와의 관계를 분석하였다. 발생 부의 형상은 발생부의 길이와 폭의 비율로 정리하여 Fig. 4 와 같이 나타내었다. 그림에서 볼 수 있는 것과 같이 상대적으로 많은 발생부에서 길이가 폭에 비해 큰 것으로 나타났다 $61 \%$, 72 개소). 또한 길이방향이 더 큰 발생부 중에서 폭에 비해 길이방 향이 1 4배 더 큰 경우가 가장 높은 빈도 $40.7 \%, 48$ 개소)를 보였다. 발생부의 심도만을 따로 분석한 결과(Fig. 5), 발생부의 심도는 $0.3 \mathrm{~m} \sim 5 \mathrm{~m}$ 의 범위를 가지며 평균값은 $1.7 \mathrm{~m}$ 로 나타샀 다. 또한 이 결과를 $0.5 \mathrm{~m}$ 간격으로 정리해보면 $0.5 \mathrm{~m} \sim 1 \mathrm{~m}$ 의 범위에서 가장 높은 빈도 $(29.7 \%, 35$ 개소)를 보였다. 동일한 결과를 Fig. 6과 같이 발생부의 길이와 폭에 대한 심도의 비율로 정리하여 비교, 분석하여 보았다. 그 결과, 발생부 심도는 대부분 길이와 폭에 비해 $15 \%$ 이하의 값을 갖는 것으로 나타났으며, 길이와 폭에 비해 심도의 값이 $5 \%$ 이하인 경우가 가장 높은 빈도를 보였다. 심도 대비 길이와 폭의 평균값은 각각 $9.5 \%$ 와 $13 \%$ 로 나타났다. 다시 한 번 정리하면 사면붕괴로 인하여

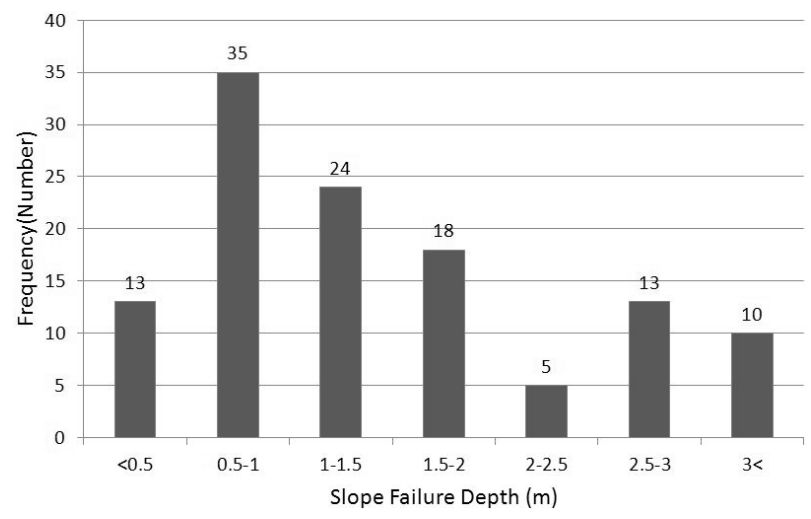

Fig. 5. Slope failure depth of initiation zone in Gangwon province (118 sites)

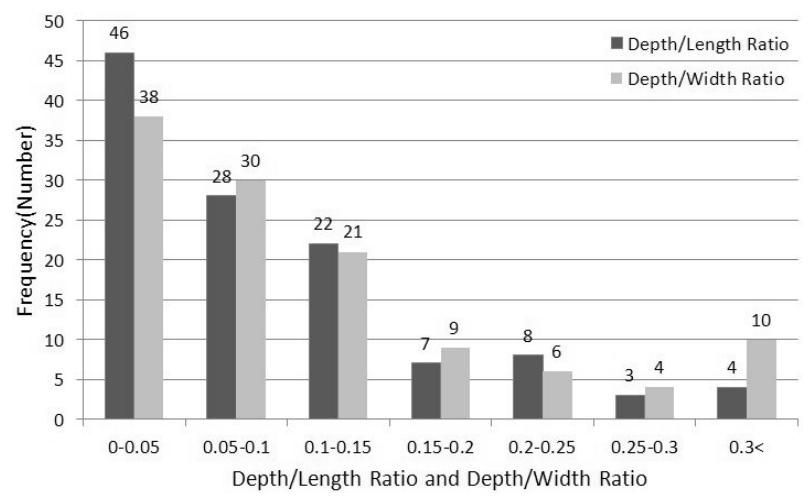

Fig. 6. Depth/length ratio and depth/width ratio of initiation zone in Gangwon province(118 sites) 
시작된 토석류 발생부는 폭에 비하여 길이가 긴 형상을 가지며, 붕괴 심도는 $2 \mathrm{~m}$ 이하로서 길이와 폭에 비하여 $15 \%$ 이하의 값을 가지는 얕은 파괴의 형태를 보인다.

\section{4. 토석류 유하부 특성}

\section{1 유하부의 평균경사}

구축된 데이터베이스를 기반으로 총 180 개소의 유하부 경사 에 대하여 분석하였다. 일반적으로 급경사에서 발생한 토석류는 주로 계곡부로 이루어진 유하부에서 이동을 하며, 유하부의 경사가 완만해지면서 $6 \sim 12^{\circ}$ 이하가 되면 퇴적하는 것으로 알려져 있다(Ikeya, 1989; Rickenmann and Zimmermann, 1993; Bathurst et al., 1997). 조사된 유하부의 길이가 다양하며 (4.2절 참고), 동일한 유하부에서도 이동거리에 따라서 점차 유하부의 경사가 완만해지므로 전체 유하부의 평균경사로 자료 를 정리하였다. 그 결과 유하부의 평균경사는 $2^{\circ} \sim 55^{\circ}$ 의 범위를 가지며, 가장 빈도가 높은 경사는 $13^{\circ}$ 로 나타났다. 또한, 전체 유하부의 평균값은 $18.1^{\circ}$ 로 나타났다. Fig. 7 에 $10^{\circ}$ 간격으로 유하부의 평균경사를 나타낸 결과, 강원지역의 경우에는 $10^{\circ}$ $\sim 20^{\circ}$ 의 범위에서 가장 높은 빈도 $(48.3 \%, 87$ 개소)를 보였다. 기존 연구에서 스위스 알프스 지역의 유하부 평균경사를 조사한 결과 $30^{\circ} \sim 40^{\circ}$ 의 범위에서 가장 높은 빈도 $(28.5 \%, 41$ 개소 $)$ 를 보였는데(Zimmermann et al., 1997), 이러한 결과로 미루어볼 때 강원지역에서 발생한 토석류가 스위스 알프스에서 발생하는 토석류보다 상대적으로 완만한 경사에서 이동한다는 것을 확인 할 수 있다.

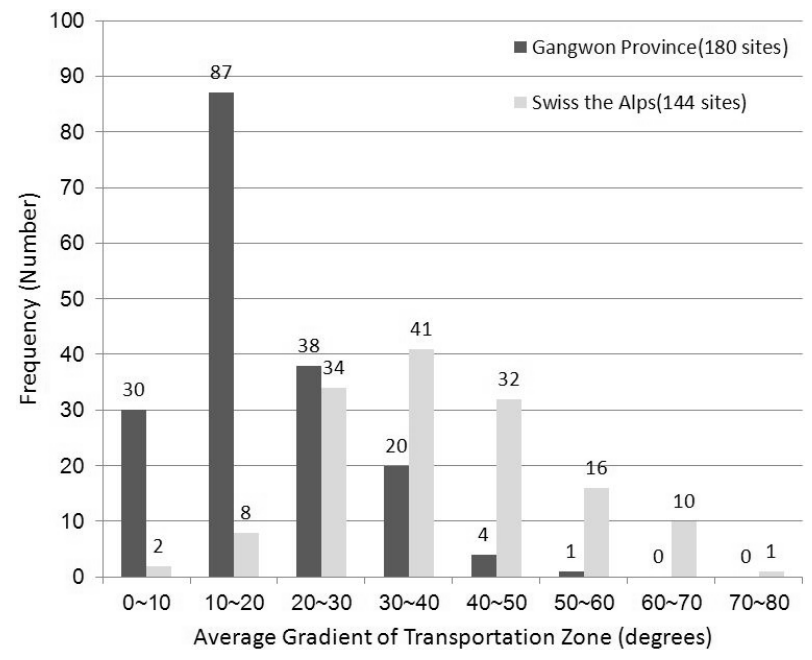

Fig. 7. Average gradient of transportation zone in Gangwon province and Swiss Alps (Swiss Alps Data from Zimmermann et al., 1997)

\section{2 유하부의 길이}

현장조사 결과를 바탕으로 토석류가 발생한 이후 유하부를 통해 이동한 총 거리를 정리하였다. 그 결과 유하부의 길이는 $41 \mathrm{~m} \sim 1,451 \mathrm{~m}$ 범위를 가지며 평균값은 $419.6 \mathrm{~m}$ 로 나타났다. 이를 Fig. 8과 같이 $200 \mathrm{~m}$ 의 간격으로 나누었을 때, 가장 높은 빈도는 $200 \mathrm{~m} \sim 400 \mathrm{~m}$ 의 범위 $(33.9 \%$, 61개소)로 나타났으며, $600 \mathrm{~m}$ 이상 이동하는 경우는 매우 적은 것으로 나타났다.

기존 연구들을 살펴보면 스위스 알프스 지역의 경우 강원 지역과 유사하게 $200 \mathrm{~m} \sim 400 \mathrm{~m}$ 정도를 이동하는 것으로 나타 났으며(VAW, 1992), 일본 Yakedake산 Kamikamihori 계곡 의 경우에는 조사된 토석류의 $57.1 \%$ 가 $600 \mathrm{~m} \sim 800 \mathrm{~m}$ 정도를 이동한 것으로 나타났다(Okuda and Suwa, 1984)(Fig. 9). 3.2절의 토석류 발생부 경사에 대한 결과와 비교하여 보면, 일본 Kamikamihory 계곡에서 발생한 토석류는 Yakedake산 이 분화되면서 분출된 입경이 작고 유동성이 큰 화산쇄설물의 특성으로 인하여 상대적으로 더 낮은 경사에서 발생하여 더 긴 거리를 이동하고 있다고 판단된다.

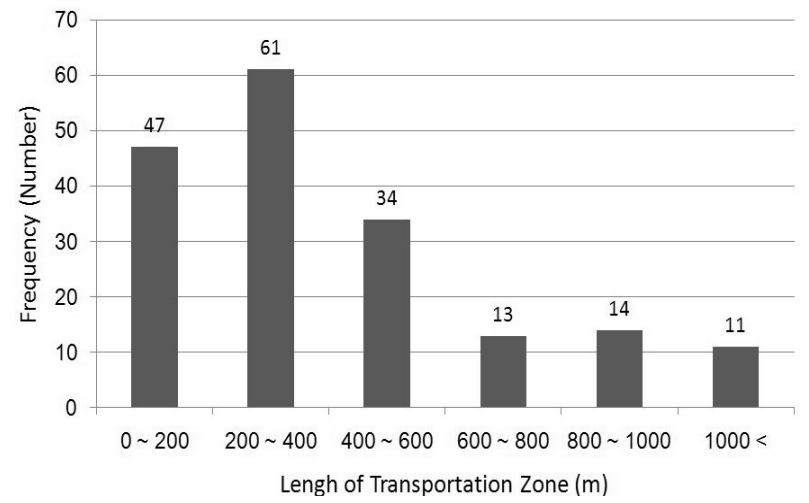

Fig. 8. Length of transportation zone in Gangwon province (180 sites)

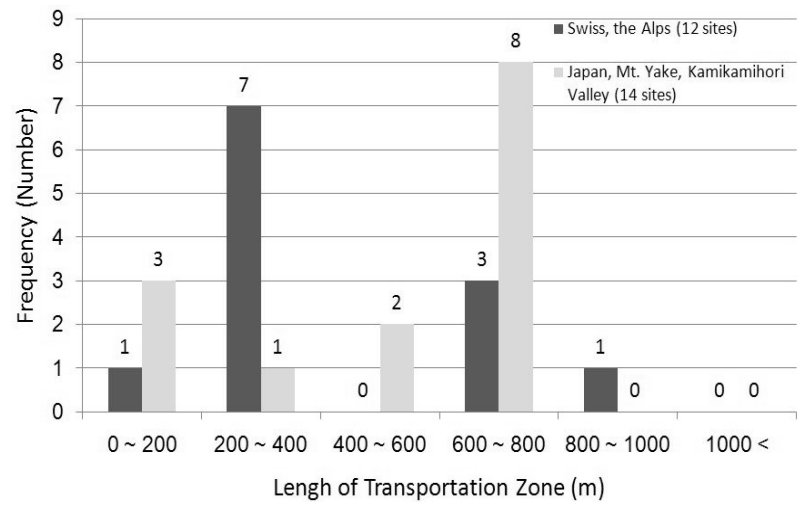

Fig. 9. Length of transportation zone in the Kamikamihori valley of the Mt. Yakedake in Japan (14 sites) and Alps in Swiss (12 sites) (VAW, 1992; Okuda and Suwa, 1984) 


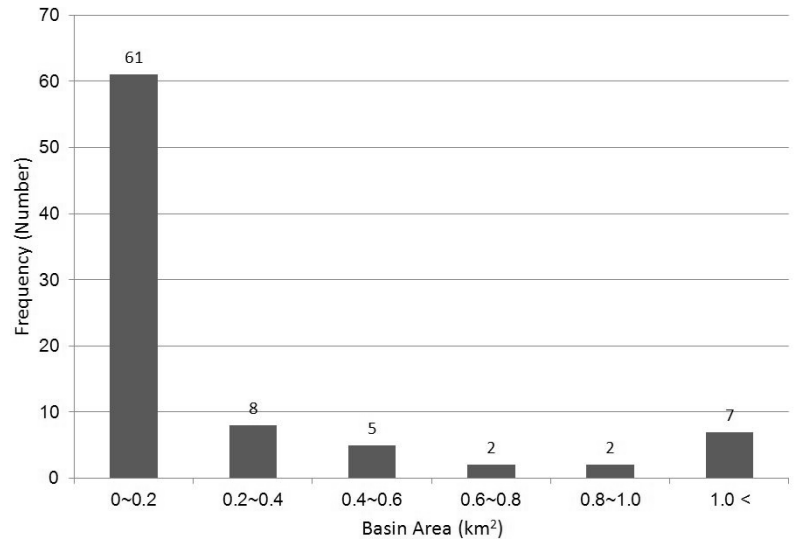

Fig. 10. Basin area of the debris flow in Gangwon province (85 sites)

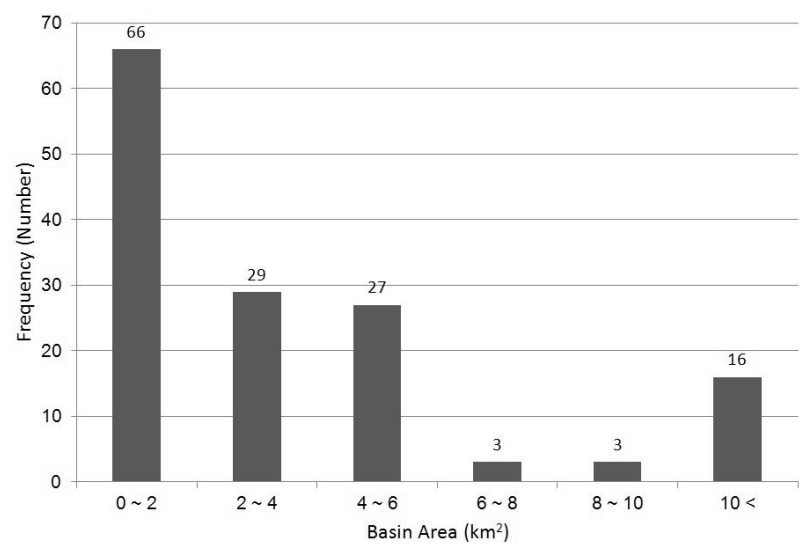

Fig. 11. Basin area of the debris flow in Alps Swiss (144 sites) (Data from Zimmermann et al., 1997)

\section{5. 토석류 발생 유역 특성}

\section{1 유역의 면적}

토석류 발생부와 유하부를 포함하는 유역의 특성을 산정하기 위하여 수치지형도를 이용하여 유역 경계를 산정한 후에 유역 전체의 면적과 평균경사, 경사방향 등을 산정하였다. 앞서 언급 한 바와 같이 하나의 유역에 대하여 출구부는 하나이지만 유역내 에서 다수의 발생부와 이동경로를 가지는 경우가 있으므로 180 개의 토석류 조사 자료를 유역별로 정리하면 총 85 개의 유역으로 나눌 수 있었다.

Fig. 10 은 총 85 개의 유역에 대해서 유역 면적을 $0.2 \mathrm{~km}^{2}$ 의 간격으로 정리한 결과이다. 강원지역의 경우 가장 높은 빈도는 $0 \mathrm{~km}^{2} \sim 0.2 \mathrm{~km}^{2}$ 의 범위 $(71.8 \%, 61$ 개소)에서 나타나 고 있으며, 그 외의 유역면적은 큰 경향성 없이 매우 낮은 빈 도를 보인다. 스위스 알프스 지역에 대한 기존의 연구 결과 (Zimmermann et al., 1997)를 Fig. 11에 도시하여 보면, 알프스

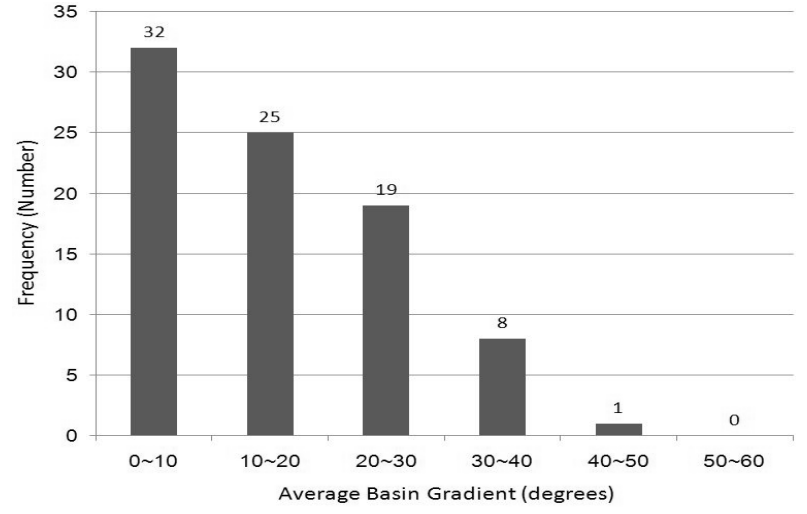

Fig. 12. Average basin gradient in Gangwon province (85 sites)

지역의 유역면적은 강원지역에 비해 약 10 배정도 더 크고, 유역면적의 증가에 비례하여 토석류의 발생빈도가 감소하는 경향을 나타내고 있다.

\section{2 유역의 평균경사}

각 유역에 대하여 $10 \mathrm{~m} \times 10 \mathrm{~m}$ 의 요소로 구성된 수치지형도 (DEM) 자료로부터 토석류 발생지역 85개소의 유역 평균경사 를 산정하였다. 산정결과, 유역의 평균경사는 $5^{\circ} \sim 46^{\circ}$ 의 범위 를 갖는 것으로 나타났으며, 구축된 전체 데이터 중 빈도가 가장 높은 경사는 $6^{\circ}$ 로 나타났고 평균값은 $15.86^{\circ}$ 로 나타났다. 또한 유역 평균경사를 $10^{\circ}$ 간격으로 정리하여 도시한 Fig. 12 를 보면, 유역의 평균경사가 증가함에 따라 빈도는 점차 감소하는 경향을 보이고 있다.

\section{3 유역의 면적과 평균경사}

Fig. 13은 미국 서부 산불지역에서 발생한 토석류에 대하 여 유역면적과 유역평균경사를 조사한 결과이다(Cannon과 Gartner, 2005). 이 연구에서는 토석류 유역면적과 평균경사를 암질에 따라서 분석을 하였으며, 그림에서 굵은 실선은 토석류 를 유발하는 임계조건을 나타낸 선이다. 이 연구에서 토석류가 발생된 유역 면적은 $0.02 \mathrm{~km}^{2} \sim 25 \mathrm{~km}^{2}$ 범위에 있으며, 25 $\mathrm{km}^{2}$ 보다 큰 유역의 출구에서는 토석류가 관측되지 않았다. 또한 유역면적이 증가하면서 유역평균경사도 점차 감소하다가 일정한 값에 수렴하는 것으로 나타나는데, 이는 유역면적이 작을 때는 유역의 경사가 급한 경우에 토석류가 발생하지만 유역면적이 증가함에 따라 완만한 경사에서도 토석류가 발생할 수 있다는 것을 의미한다. 반면에 암질조건은 유역 면적과 유역 평균경사에는 큰 영향을 주지 않는 것으로 나타났다.

Fig. 14는 동일한 방법으로 강원지역의 토석류 발생지로부터 얻은 자료를 이용하여 나타낸 그래프이다. Fig. 13과의 비교를 


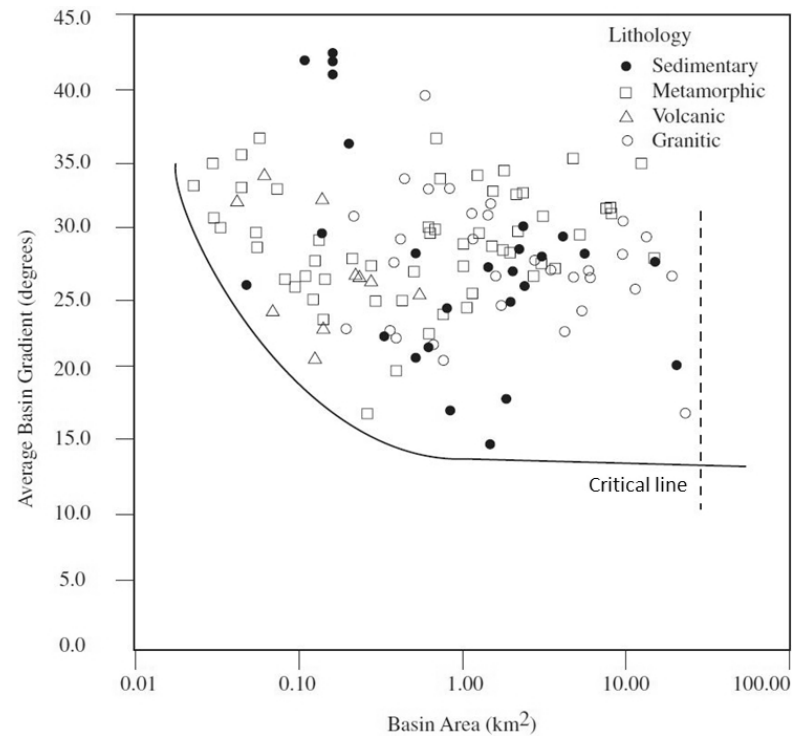

Fig. 13. Relations between basin area and average basin gradient of basins producing fire-related debris flows in the western U.S. (Cannon and Gartner, 2005)

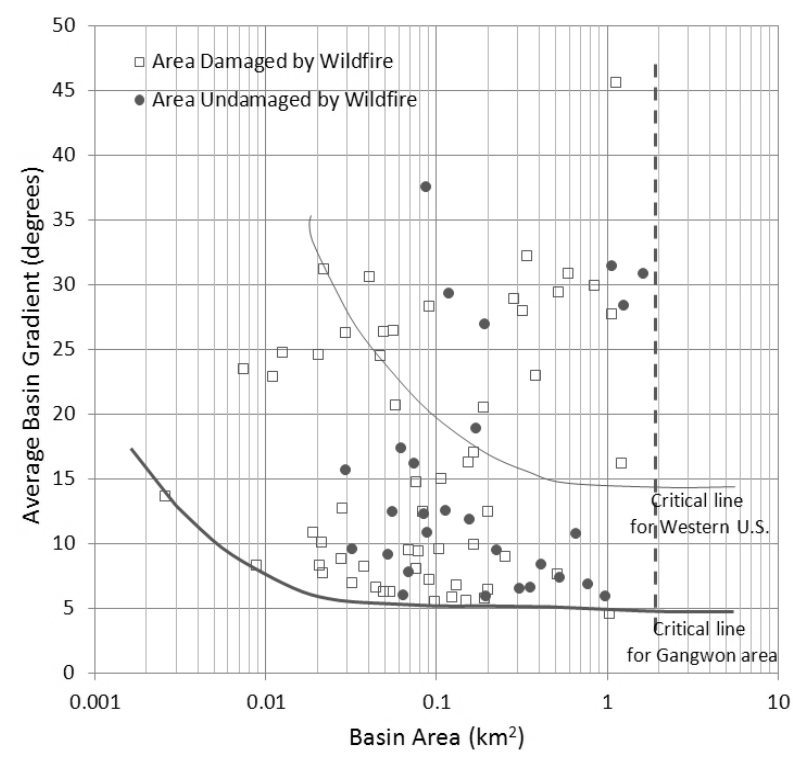

Fig. 14. Relations between basin area and average basin gradient of basins producing debris flows in Gangwon province (85 sites)

위하여 굵은 실선으로 표시한 강원지역의 임계조건위에 Fig. 13 에서의 임계선을 가는 실선으로 표시하였다. 또한 과거 10 년 동안의 강원지역 산불 발생자료를 수집하여 토석류 발생지역을 산불발생지역과 산불미발생지역으로 구분하여 도시하였다. 미 국 서부지역과 강원지역의 임계조건을 비교해본 결과, 유역 면적과 유역 평균경사의 분포 형태는 유사하지만, 강원지역이 미국 서부지역에 비하여 토석류 발생 유역은 약 $1 / 10$ 배 정도로

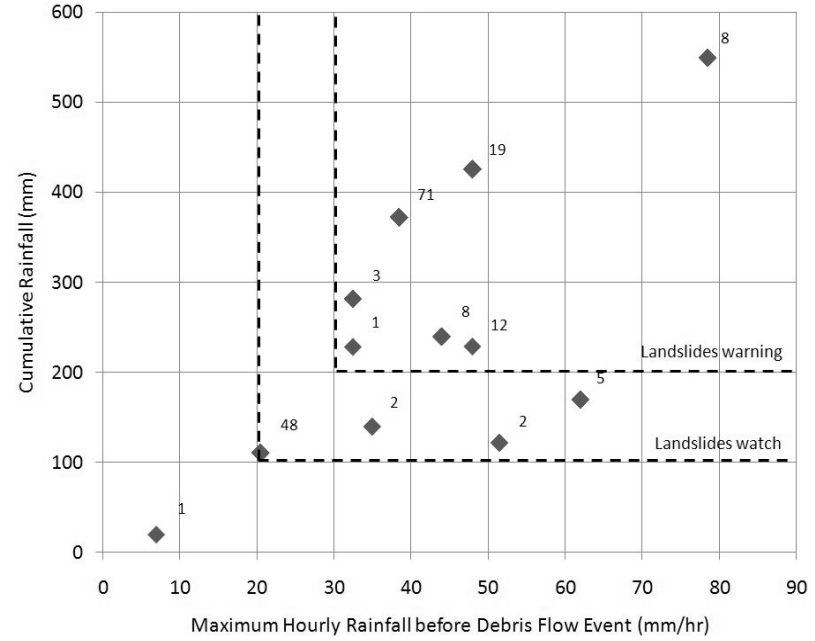

Fig. 15. Relations of the maximum hourly rainfall and antecedent cumulative rainfall before occurrence of debris flow (180 sites)

작으며 유역 평균경사 역시 약 $10^{\circ} \sim 20^{\circ}$ 정도 더 작은 것으로 나타났다. 하지만 기존연구(Yune et al., 2010)에서 강원지역의 산불발생지역이 토석류를 포함한 사면재해 발생에 있어 강우에 는 취약한 것으로 나타난 것과는 반대로 산불발생유무가 토석류 를 유발하는 유역 면적과 유역 평균경사에는 큰 영향을 주지 않는 것으로 나타났다.

\section{6. 토석류 유발강우}

토석류 유발강우 분석에 사용된 강우자료는 가상청 자동기상 관측시스템(AWS)의 시간강우자료를 사용하였으며, 토석류 발 생지와 가장 가까운 기상관측소의 강우자료를 사용하였다. 각각 의 토석류 발생지별 토석류 발생시간에 대한 강우자료를 사용하 여 토석류 발생 이전 최대시간강우량과 연속강우량관계를 다음 Fig. 15에 나타내었으며, 산림청의 산사태 예보 및 경보 기준을 함께 표시하였다. 조사된 지역에 비하여 기상청 기상관측시스템 의 개수가 적기 때문에 다수의 발생부가 하나의 기상자료를 공유하는 경우가 있어 그림에 각 강우자료 별로 발생부의 개소수 를 함께 표시하였다. 이 그림에서 연속강우량은 최대시간강우량 과 함께 증가하는 경향을 보이며, 하나의 값을 제외한 모든 값들이 산림청 산사태 예보기준 내에 있는 것으로 나타났다. 다만 시간강우량은 발생이전의 최대시간강우량이므로 강원지 역에서 발생하는 토석류는 일반적인 산사태 예보 기준보다 더 큰 강우가 내린 후에 발생하는 것으로 판단된다.

동일한 강우자료를 행정구역별로 나누어 토석류 발생이전 1일누적, 2 3일누적, 4 28일 누적강우량으로 Fig. 16과 같이 


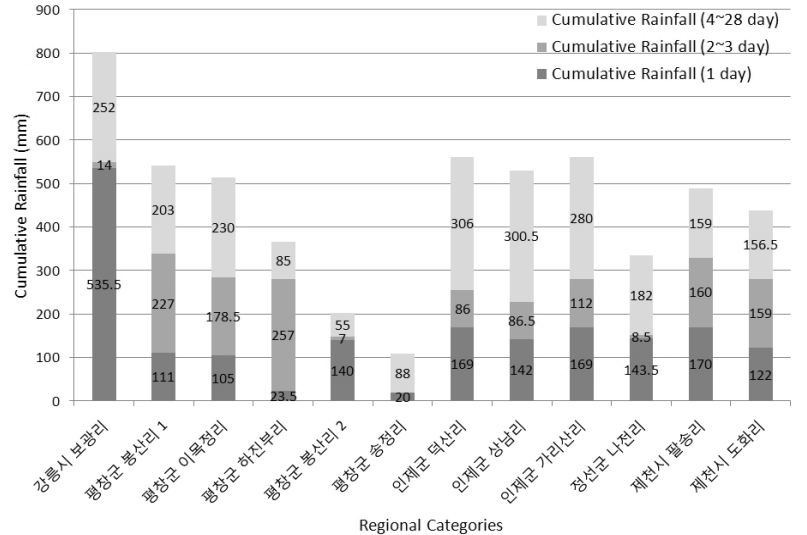

Fig. 16. Cumulative rainfall for regions in Gangwon province (12 regions)

정리하였으며, 이를 이용하여 토석류 발생 이전의 선행강우의 영향에 대하여 분석하였다. 분석 결과, 총 12 개의 행정 지역 중 발생 당일의 누적강우량이 가장 큰 경우는 3 개 지역이었으며, 발생 이전 2 3일누적 강우량이 가장 큰 경우는 3 개 지역, 그리고 발생 이전 4 28일 누적강우량이 가장 큰 경우는 6개 지역으로 나타나, 토석류 발생 이전의 선행 누적강우량이 토석류 발생 당시의 시간강우량과 함께 토석류를 유발하는 중요한 인자라고 판단된다. 특히 발생 당일의 강우도 중요하지만 발생 이전의 장기강우가 토석류 발생과 밀접한 관련이 있다는 사실을 유추할 수 있으며, 토석류 발생이전의 장기적인 강우로 인한 토층의 포화도 증가가 이후 상대적으로 적은 강우에서도 토석류를 발생시킨 원인이 되었던 것으로 보인다. 하지만 토석류를 유발 하는 강우의 특성을 명확히 규명하기 위해서는 향후 더 많은 연구가 필요할 것으로 판단된다.

\section{7. 결 론}

이 연구에서는 강원지역에서 발생된 토석류 발생지에 대한 현장조사를 실시하고, 강우자료 및 수치지형자료 등을 취합하여 총 180 개 현장에서 발생한 토석류 DATABASE를 구축하였다. 구축된 자료를 바탕으로 발생부, 유하부, 그리고 유역에 대한 지형학적 특성과 강우에 대한 분석을 수행하여 다음과 같은 결론을 얻었다.

(1) 토석류 발생부의 부피는 $16 \mathrm{~m}^{3} \sim 18,450 \mathrm{~m}^{3}$ 의 범위를 가지며 대부분 $1,000 \mathrm{~m}^{3}$ 미만의 소규모 사면파괴로부터 시작된 것으로 나타났다. 또한 발생부는 대부분 폭에 비해 길이가 긴 형태의 평면파괴였으며, 평균심도는 $1.7 \mathrm{~m}$ 로서 대부분 길이 및 폭에 대하여 $15 \%$ 이하의 값을 갖는 얕은
파괴로 발생한 것으로 나타났다.

(2) 토석류의 발생은 지역의 지형학적 특성들과 관련되는데, 강원지역에서는 평균 $34.3^{\circ}$ 정도의 비교적 가파른 경사에서 토석류가 발생하여 평균 $18.1^{\circ}$ 정도의 완만한 경사에서 계곡을 따라 $420 \mathrm{~m}$ 정도의 비교적 짧은 거리를 이동하는 것으로 나타났다.

(3) 강원지역에서 발생한 토석류의 유역면적은 대부분 $1.2 \mathrm{~km}^{2}$ 미만으로써, 미국 서부지역과 스위스의 알프스지역에 비해 약 $1 / 10$ 배 정도로 매우 작았으며, 평균 유역경사는 $15.86^{\circ}$ 로 나타났다.

(4) 토석류 발생이전에 산림청의 산사태 예보 기준을 넘어서는 강우가 있었다는 것을 확인할 수 있었다. 또한 토석류 발생 당일의 강우도 중요하지만 발생 이전의 장기강우가 토석류 발생과 밀접한 관련이 있는 것으로 나타나, 토석류 발생 이전의 선행 누적강우량이 토석류 발생 당시의 시간강우량 과 함께 토석류를 유발하는 중요한 인자라고 판단된다.

\section{감사의 글}

본 연구는 국토해양부 지역기술혁신사업의 연구비 지원(‘ 08 지역기술혁신 B01-01)에 의해 수행되었으며, 이에 감사드립니 다. 또한 현장조사에 함께 참여해주신 강원대학교 유남재 교수 님, 강릉영동대학 서흥석 교수님, 도로교통연구원 김경석 박사 님께 감사드립니다.

\section{References}

Bathurst, J. C., Burton, A., and Ward, T. J. (1997), Debris flow runout and landslide sediment delivery model tests. Journal of Hydraulic Engineering, 123(5), pp. 410-419.

Cannon, S. H., and Gartner, J. E. (2005), "Wildfire-related debris flow from a hazards perspective", Debris-flow Hazards and Related Phenomena, Ch. 15, pp. 363-385.

Ikeya, H. (1989), "Debris Flow and Its Countermeasures in Japan", Bulletin International Association of Engineering Geologists, No. 40, pp. 15-33.

Jakob, M., and Hungr, O. (2005), Debris-flow Hazards and Related Phenomena.

Kim, K. S., Kim, W. Y., Chae, B. G., Cho, Y. C., Lee, C. O., and Song, Y. S. (2006), "Geometry of Debris Flow Occurrence on Natural Slopes”, KSEG Conference 2006, KSEG, Daejeon, Korea, pp. 51-59.

Ministry of Construction and Transportation (2006), Investigation report on the damages by the Typhoon and intensive rainfall on July 2006, GOVP1200713914, Ministry of Land, Transport and Maritime Affairs. 
National Disaster Management Institute (2002), The Field Survey Report of Damages Caused by the Typhoon RUSA in 2002, NIDP-2002-02(Field Survey Report), National Disaster Management Institute.

National Disaster Management Institute (2003), Field Survey Report of Damages Caused by Typhoon Maemi in 2003-Damaged by Flood, Storm Surge, Electric Power System Failure (9.12 9.13), NIDP-2003-02(Field Survey Report), National Disaster Management Institute.

Okuda, S., and Suwa, H. (1984), "Some relationships between debris flow motion and micro-topography for the Kamikamihori fan, North Japan Alps. In: T.P. Burt and D.E. Walling(eds)", Catchment Experiments in Fluvial Geomorphology. GeoBooks, Norwick, UK., pp. 447-464.

Rickenmann, D., and Zimmermann, M. (1993), The 1987 debris flows in Switzerland: Documentation and analysis. Geomorphol- ogy, 8, pp. 175-189.

VAW (1992), "Murgange 1987: Dokumentation und Analyse" (unpublished report, No. 97.6, pp. 620). Versuchsanstalt fur Wasserbau, Hydrologie und Glaziologie, ETH, Zurich [in German]. Yoo, N. J., Jun, S. H., and Park, N. S. (2008), A Study on Characteristics of Landslides of Debris Flow in Gangwon-do, Research Report the Institute of Industrial Technology, Vol. 28, No. A, pp. 3-10.

Yune, C. Y., Jun, K. J., Kim, K. S., Kim, G. H., and Lee, S. W. (2010), Analysis of Slope Hazard-Triggering Rainfall Characteristics in Gangwon Province by Database Construction, Journal of Korean Geotechnical society, Vol. 26, No. 10, pp. 27-38.

Zimmermann, M., Mani, P., Gamma, P., Gsteiger, P., Heiniger, O., and Hunziker, G. (1997), Murganggefahr und Klimaanderung: ein GIS-Basierter Ansatz, vdf HochschulverlagAG, ETH, Zürich [in German]. 